Listening Subjects 



\title{
LISTENING SUBJECTS
}

\author{
Music, \\ Psychoanalysis,
}

Culture

DAVID SCHWARZ

Duke University Press

Durbam \& London 
(C) 1997 Duke University Press

All rights reserved

Printed in the United States of America

on acid-free paper $@$

Typeset by Tseng Information Systems, Inc.

Typeset in ITC Carter and Cone Galliard

Library of Congress Cataloging-in-

Publication Data appear on the last

printed page of this book. 
for Jakob and Marlies 
